\title{
Systemic lupus erythematosus: what should family physicians know in 2018 ?
}

\author{
CC Mok *
}

This article was published on 28 Sep 2018 at www.hkmj.org.

\section{A B S T R A C T}

Systemic lupus erythematosus (SLE) is a complex multi-systemic autoimmune disease with considerable clinical and immunological heterogeneity. Family physicians should be familiar with the protean manifestations of SLE to aid early diagnosis and monitoring of disease progression. The role of family physicians in SLE includes education, counselling, psychological support, management of mild disease, and recognition of the need for referral to other specialists for more serious disease and complications. Surveillance of cardiovascular risk factors and osteoporosis and advice about vaccination and reproductive issues can be performed in the primary care setting under close collaboration with rheumatologists and other specialists. This review provides family physicians with the latest classification criteria for SLE, recommendations on SLE-related health issues, and pharmacological therapies for SLE.

\section{Hong Kong Med J 2018;24:501-11}

DOI: $10.12809 / \mathrm{hkmj} 187319$

CC Mok *, MD, FRCP

Department of Medicine, Tuen Mun Hospital, Tuen Mun, Hong Kong

* Corresponding author: ccmok2005@yahoo.com

\section{Introduction}

Systemic lupus erythematosus (SLE) is a prototypical multi-systemic autoimmune disease that predominantly affects women of childbearing age. The disease has considerable clinical and immunological heterogeneity; no two patients with SLE are exactly alike. The pathogenesis of SLE remains obscure, with multiple genetic, epigenetic, hormonal, and immunopathological pathways being involved. ${ }^{1}$ The course of SLE is largely unpredictable and characterised by periods of disease exacerbation and remission that lead to progressive organ damage and dysfunction. ${ }^{2}$ Compared with the age- and sex-matched general population, SLE is associated with at least a five-fold increase in mortality. ${ }^{3}$ Patients with SLE have reduced quality of life because of multiple factors, such as organ damage, anxiety, and depression. ${ }^{4,5}$

In Hong Kong, the prevalence and annual incidence of SLE are estimated to be $0.1 \%$ and 6.7 per 100000 population, respectively. ${ }^{6}$ The 15 -year cumulative survival of local Chinese patients with SLE managed in non-academic hospitals is $86 \%$. $^{7}$ Infections, cardiovascular events, and malignancies are their most common causes of death. Renal and musculoskeletal complications (eg, avascular bone necrosis and osteoporotic fracture) are the most important contributors to disease and treatmentrelated organ damage, respectively. One-third of such patients lose their ability to work within 5 years after disease onset; this is mainly attributed to musculoskeletal pain, fatigue, anxiety/depression symptoms, and memory deterioration. ${ }^{8}$
Strategies for management of SLE by family physicians should target early recognition and diagnosis, treatment and monitoring of mild disease, and referral to specialists to formulate an individualised plan based on age, disease severity, organ function, and other medical co-morbidities. ${ }^{9}$ In this article, the latest criteria for classification of SLE, use of autoantibodies for diagnosis and assessment, the role of family physicians, disease monitoring, advice on various SLE-related health issues from a local perspective, and pharmacological treatment of the disease will be reviewed.

\section{Classification criteria for systemic lupus erythematosus}

The manifestations of SLE are protean, and any body system can be involved during the course of the disease. In our experience with 803 Hong Kong Chinese patients with SLE, the most common features are arthritis, glomerulonephritis, facial rash, and haematological disease (Fig). ${ }^{7}$ In primary care practice, the most frequently encountered early symptoms of SLE include systemic upset (fatigue, fever, weight loss, loss of appetite, and prolonged influenza-like illness), arthralgia or arthritis, facial rash, photosensitivity, mouth sores, pleuritic chest pain, and Raynaud's phenomenon. ${ }^{6}$ In hospital practice, more serious manifestations of SLE such as rapidly progressive glomerulonephritis, pulmonary haemorrhage, cardiac tamponade, severe cytopenia, and neuropsychiatric symptoms may be encountered. 


\section{家庭醫生對系統性紅斑狼瘡的最新治療須知}

\section{莫志超}

系統性紅斑狼瘡 (SLE) 是一種複雜的多系統自身免疫疾病, 具有相 當大的臨床和免疫異質性。家庭醫生應熟悉SLE千變萬化的臨床表 現, 有助及早診斷和監測疾病進展。家庭醫生的角色在於教育、輔 導、心理支持及治療輕度疾病的患者, 以及發現更嚴重疾病和併發症 時轉介其他專科醫生治療SLE。家庭醫生可透過與風濕病學家和其他 專家的密切合作下, 在初級保健機構中對SLE患者的心血管危險因素 和骨質疏鬆症進行監測, 並提供有關疫苗接種和生殖問題的建議。本 文為家庭醫生提供SLE最新分類標準、SLE相關健康問題的建議，以 及SLE的藥物治療

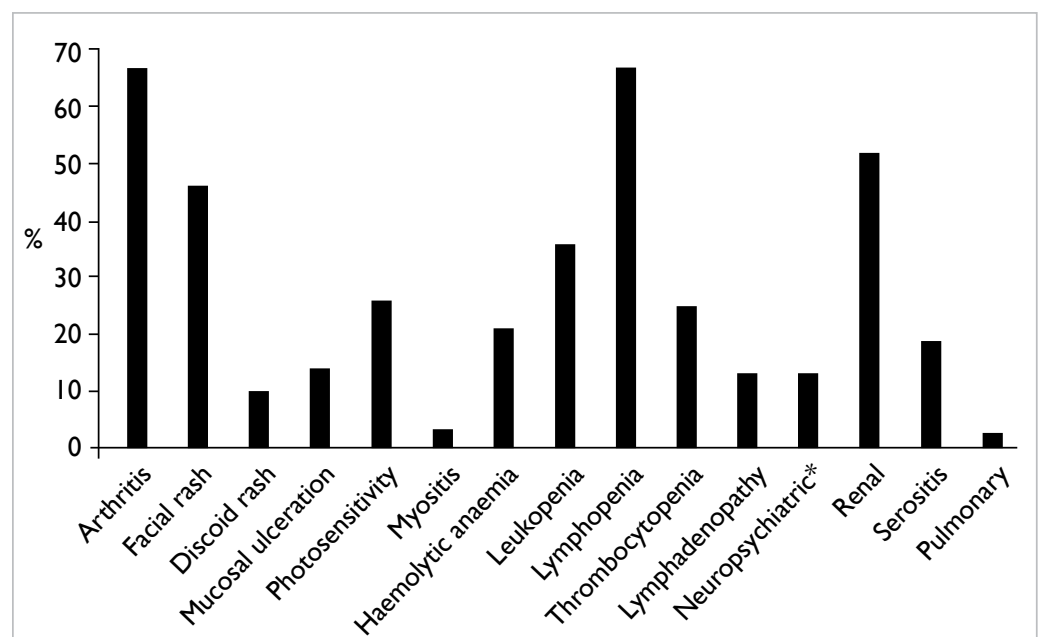

FIG. Cumulative frequencies of clinical manifestations of systemic lupus erythematosus in Hong Kong Chinese

* Neuropsychiatric includes only psychosis, seizure, acute confusional state, myelitis, peripheral and cranial neuropathy, mononeuritis multiplex, optic neuritis, myasthenia gravis, and movement disorders
The American College of Rheumatology (ACR) classification criteria for SLE were established in $1982,{ }^{10}$ and this set of criteria was revised in $1997,{ }^{11}$ with the deletion of the LE cell phenomenon and the addition of antiphospholipid antibodies as a criterion. A classification of SLE is made when four or more of the 11 clinical or serological criteria are fulfilled serially or simultaneously. However, in real life practice, many patients with autoimmune cytopenia or hypocomplementaemia are treated as having SLE, even though they do not fulfil the 1997 criteria. ${ }^{11}$ Moreover, dermatological manifestations other than malar rash and discoid lesions and neuropsychiatric manifestations other than psychosis and seizure are not included in the criteria. Owing to these limitations, the Systemic Lupus International Collaborating Clinics (SLICC) group revised and validated a new set of classification criteria in 2012. ${ }^{12}$ A patient is classified as having SLE when at least four of the 17 SLICC/ACR criteria are fulfilled. A comparison of the 1997 ACR and 2012 SLICC criteria is shown in Table 1.

The SLICC group emphasises the absolute requirement of at least one clinical or immunologic criterion for a classification of SLE. Lupus malar rash and photosensitivity are no longer separated into two criteria. There is no need to demonstrate the absence of radiological erosion in lupus arthritis. A number of types of subacute and chronic lupus skin lesions are included, and diffuse non-scarring alopecia (excluding alopecia areata or other causes) is also regarded as a criterion for SLE classification. Haemolytic anaemia, leukopenia/lymphopenia, and thrombocytopenia are separated into three criteria, and more neuropsychiatric features are included in addition to psychosis and seizure. For the renal criteria, the dipstick test for urine protein is replaced by either the protein-to-creatinine ratio (spot urine test) or 24-hour urine protein quantification. Finally, an entity called "stand-alone" lupus nephritis is introduced, in which a patient has typical renal biopsy features of lupus nephritis and a positive ANA or anti-dsDNA antibody test in the absence of other features of SLE. The features in the SLICC criteria must be related to active SLE instead of other causes or differential diagnoses. Validation of the SLICC criteria has demonstrated higher sensitivity (97\% vs $83 \%$ ) but lower specificity (84\% vs 96\%) for SLE than the 1997 ACR criteria. ${ }^{12}$

To further improve the sensitivity and specificity of SLE classification, the ACR/EULAR (European League Against Rheumatism) is currently validating a new set of criteria consisting of an entry criterion and 10 domains (seven clinical and three immunologic). More items with different weighted scores are included. Applications on mobile devices and desktop computers will be devised to facilitate the calculation of summed scores for classification purposes.

These classification criteria for SLE are being developed to facilitate research and comparison among different cohorts of patients. Although they generally have good specificity to aid diagnosis, false positivity and negativity are bound to occur. The final diagnosis of SLE still requires the meticulous clinical judgement of attending physicians.

\section{Antinuclear antibody for diagnosis of systemic lupus erythematosus}

Antinuclear antibody (ANA) is the hallmark of SLE. Although this antibody shows extreme sensitivity for SLE (>98\%), it has low specificity. As many as $20 \%$ to $23 \%$ of normal healthy individuals test positive 
TABLE I. Classification criteria for SLE

\begin{tabular}{|c|c|c|}
\hline & 1997 ACR criteria11 & 2012 SLICC/ACR criteria ${ }^{12}$ \\
\hline No. of clinical criteria & 9 & 11 \\
\hline Dermatological & $\begin{array}{l}\text { 1. Malar rash (fixed erythema, flat or raised, over the malar } \\
\text { prominence, tending to spare the nasolabial folds) } \\
\text { 2. Photosensitivity }\end{array}$ & $\begin{array}{l}\text { 1. Acute cutaneous lupus (malar rash, photosensitive rash, } \\
\text { bullous lupus, toxic epidermal necrolysis variant of SLE, } \\
\text { maculopapular rash) OR subacute cutaneous lupus rash }\end{array}$ \\
\hline Dermatological & 3. Discoid lupus (typical) & $\begin{array}{l}\text { 2. Chronic cutaneous lupus (classic discoid, hypertrophic } \\
\text { [verrucous] lupus, panniculitis [profundus], mucosal } \\
\text { lupus, lupus tumidus, chilblains lupus, discoid lupus/ } \\
\text { lichen planus overlap) }\end{array}$ \\
\hline Mucosal & $\begin{array}{l}\text { 4. Oral/nasal ulcers (usually painless, observed by } \\
\text { physician) }\end{array}$ & 3. Oral/nasal ulcers \\
\hline Alopecia & - & $\begin{array}{l}\text { 4. Non-scarring diffuse alopecia (excluding alopecia areata, } \\
\text { androgenic alopecia, or other causes, eg, drugs) }\end{array}$ \\
\hline Musculoskeletal & $\begin{array}{l}\text { 5. Non-erosive arthritis in } \geq 2 \text { joints (tender, swollen or } \\
\text { effusion) }\end{array}$ & $\begin{array}{l}\text { 5. Synovitis } \geq 2 \text { joints (swelling or effusion) OR tenderness } \\
\geq 2 \text { joints and } \geq 30 \text { minutes of morning stiffness }\end{array}$ \\
\hline Serositis & 6. Pleurisy OR pericarditis & $\begin{array}{l}\text { 6. Typical pleurisy }>1 \text { day OR pleural effusion OR pleural } \\
\text { rub; typical pericardial pain }>1 \text { day OR pericardial } \\
\text { effusion OR pericardial rub OR pericarditis by } \\
\text { electrocardiography }\end{array}$ \\
\hline Haematologic & $\begin{array}{l}\text { 7. Haemolytic anaemia with reticulocytosis OR leukopenia } \\
\left(<4000 / \mathrm{mm}^{3} \text { at least twice) OR lymphopenia }\left(<1500 / \mathrm{mm}^{3}\right.\right. \\
\text { at least twice) OR thrombocytopenia }\left(<100 / \mathrm{cm}^{3}\right)\end{array}$ & $\begin{array}{l}\text { 7. Haemolytic anaemia } \\
\text { 8. Leukopenia }\left(<4000 / \mathrm{mm}^{3} \text { at least once) OR lymphopenia }\right. \\
\left(<1000 / \mathrm{mm}^{3} \text { at least once) }\right. \\
\text { 9. Thrombocytopenia }\left(<100 / \mathrm{cm}^{3} \text { at least once }\right)\end{array}$ \\
\hline Renal & $\begin{array}{l}\text { 8. Proteinuria }>500 \mathrm{mg} / \mathrm{day} \text { or }>3+\text { by dipstick } \text { OR cellular } \\
\text { cast (RBC, haemoglobin, granular, tubular, or mixed) }\end{array}$ & $\begin{array}{l}\text { 10. Urine protein-to-creatinine ratio (or 24-hour urine protein) } \\
>500 \mathrm{mg} \text { protein/24 hours OR RBC casts }\end{array}$ \\
\hline Neuropsychiatric & 9. Seizure OR psychosis & $\begin{array}{l}\text { 11. Seizures, psychosis, mononeuritis multiplex, myelitis, } \\
\text { peripheral OR cranial neuropathy }\end{array}$ \\
\hline $\begin{array}{l}\text { No. of serological } \\
\text { criteria }\end{array}$ & 2 & 6 \\
\hline $\begin{array}{l}\text { Immunologic/ } \\
\text { serological }\end{array}$ & $\begin{array}{l}\text { 1. Positive ANA (not induced by drugs) } \\
\text { 2. Positive for anti-dsDNA OR anti-Sm OR antiphospholipid } \\
\text { antibodies (IgG/IgM anticardiolipin; lupus anticoagulant; } \\
\text { or a false positive serologic test for syphilis known to be } \\
\text { positive for } \geq 6 \text { months) }\end{array}$ & $\begin{array}{l}\text { 1. Positive ANA (above laboratory reference range) } \\
\text { 2. Anti-dsDNA (above laboratory reference range or }>2 \text {-fold } \\
\text { the reference range if tested by ELISA) } \\
\text { 3. Anti-Sm positivity } \\
\text { 4. Antiphospholipid antibody positivity: positive lupus } \\
\text { anticoagulant, false positive result for rapid plasma } \\
\text { regain, medium-/high-titre anticardiolipin (lgG/A/M), or } \\
\text { anti- } \beta_{2} \text { glycoprotein I (lgG/A/M) } \\
\text { 5. Low complements (C3/C4/CH50) } \\
\text { 6. Positive direct Coombs' test (in the absence of } \\
\text { haemolytic anaemia) }\end{array}$ \\
\hline Total No. of criteria & 11 & 17 \\
\hline SLE classification & $\geq 4 / 11$ Criteria & $\geq 4 / 17$ Criteria \\
\hline
\end{tabular}

Abbreviations: $\mathrm{ACR}=$ The American College of Rheumatology; ANA = antinuclear antibody; ELISA = enzyme-linked immunosorbent assay; $\mid \mathrm{g}=$ immunoglobulin; RBC = red blood cells; SLE = systemic lupus erythematosus; SLICC = Systemic Lupus International Collaborating Clinics

for ANA, particularly older subjects. ${ }^{13}$ Other autoimmune and non-immune chronic illnesses also generate positivity for ANA, making it grossly unsuitable as a sole diagnostic test. However, ANA is an excellent screening test for SLE, and a negative result by indirect immunofluorescence assay (IIFA) may virtually exclude the diagnosis.

Antinuclear antibody is conventionally detected by the IIFA method, which involves initial screening, serial serum dilution, and determination of the distinct ANA staining patterns on human epithelial cell (HEp-2) slides. ${ }^{14}$ This is the most sensitive method of ANA detection, but it is labour- intensive and subject to inter-observer reading variability. Although IIFA remains the gold standard of ANA detection, automated and less laborious quantitative methods are often used by service laboratories. Enzyme-linked immunosorbent assay is commonly used to detect serum autoantibodies directed against antigens coated onto plates. ${ }^{15}$ As the antigens used may be derived from animal tissues or recombinant techniques, the specificity and sensitivity of the results for assessment of SLE vary among different commercial kits adopted by different laboratories. In general, higher ANA titres result in more specific predictions for SLE and related 
disorders. Therefore, ANA should be interpreted in the clinical context, and a diagnosis of SLE should not be based on a positive ANA result alone.

The dense fine speckle (DSF) pattern of ANA in IIFA is related to autoantibodies against a $70-\mathrm{kDa}$ protein (DSF70). ${ }^{16}$ Interestingly, this anti-DSF70 antibody is present in around one-third ${ }^{16-19}$ of ANApositive healthy subjects, in contrast to less than $1 \%$ of ANA-positive patients with SLE and other autoimmune diseases. ${ }^{20}$ Anti-DSF70 is becoming a part of the standard report along with the ANA result in public hospitals. Positive results for both ANA and anti-DSF70, in the absence of other autoantibodies such as anti-dsDNA and anti-extractable nuclear antigen (anti-ENA), may virtually exclude SLE or an ANA-related autoimmune disorder.

\section{Systemic lupus erythematosus diathesis recognition}

Table 2 shows a list of pointers that should alert family physicians to consider the possibility of SLE. ${ }^{21}$ When SLE is suspected, ANA should be included in the screening blood tests. If the patient is positive for ANA, more specific tests such as those for anti-dsDNA, anti-ENA, antiphospholipid antibodies (eg, anticardiolipin antibodies), and complements are needed to confirm the diagnosis. Other relevant investigations are also needed, such as urine analysis, cell counts, renal and liver function tests, and tests for inflammatory markers such as erythrocyte sedimentation rate or C-reactive protein (CRP). Diagnosis of SLE is based on a combination of compatible clinical features and the presence of

TABLE 2. Diagnostic pointers to systemic lupus erythematosus $^{21}$

\begin{tabular}{l}
\hline 1. Female sex \\
2. Age $<45$ years \\
3. No joint erosion despite having arthritis for $\geq 2$ years \\
4. Unexplained lymphopenia \\
5. History of "growing pains" in childhood \\
6. History of drug allergies \\
7. History of "epilepsy" in childhood \\
8. Alopecia \\
9. Unexplained postpartum fever \\
10. Recurrent abortions \\
11. Livedo reticularis on physical examination \\
12. Positive immunofluorescence tests on skin biopsy \\
13. High erythrocyte sedimentation rate but normal \\
14. Unexplained low complement levels \\
15. Simultaneous involvement of multiple organs \\
\hline
\end{tabular}

relevant immunological abnormalities. Therefore, SLE should never be diagnosed by abnormal antibody tests alone.

The ANA titre is not useful for monitoring of SLE activity. The anti-dsDNA titre and complement levels $(\mathrm{C} 3 / 4)$ are the standard serological tests for disease activity evaluation ("lupus serology"). The ENAs include a number of soluble cytoplasmic and nuclear antigens. The six main antigens used to detect anti-ENA antibodies are Ro, La, Sm, RNP, Scl-70, and Jo-1. The detected antibodies are associated with certain manifestations of SLE (eg, anti-Ro with cutaneous lupus and photosensitivity) and are relevant in pregnancy (eg, anti-Ro with congenital heart blockage and neonatal lupus). Anti-Sm is specific to SLE and is a criterion for its classification. ${ }^{11,12}$ As anti-ENA antibodies seldom sero-convert over time, repeating the tests during routine follow-up is not necessary. Table 3 summarises the assessment and monitoring of patients with SLE and includes general advice about various health-related issues.

\section{Role of family physicians}

According to our experience with Chinese patients with SLE, mood disorders are its most frequent psychiatric manifestations..$^{22}$ The major self-reported symptoms that lead to impaired quality of life are problems with memory and concentration and symptoms of anxiety and depression..$^{23}$ Therefore, patients with SLE should receive education about the disease, psychological counselling, and support in the primary care setting.

In addition to understanding the clinical presentation of SLE for early diagnosis, trained family physicians are able to treat and monitor mild SLE, which comprises the following characteristics: (1) diagnosis clearly established; (2) clinically stable; (3) absence of life-threatening manifestations; (4) stable function of organ systems; and (5) absence of significant complications related to disease activity or treatment. Patients with stable SLE should be followed at intervals of 3 to 6 months. Referral to specialists is indicated for worsening disease activity, involvement of major organs such as the kidneys, haematological and central nervous system complications, development of disease or treatmentrelated complications, antiphospholipid syndrome, and advice about pregnancy, surgery, and other special circumstances. ${ }^{21}$

Family physicians may help to monitor disease activity and the adverse effects of drug therapies. A complete blood count, renal function, SLE serology (anti-dsDNA and complements), and urinary protein analysis should be performed every 3 to 6 months for patients with stable disease. As patients with SLE are more prone to accelerated atherosclerosis as a result of disease activity and 
TABLE 3. Assessment and monitoring of patients with SLE and general advice

\begin{tabular}{|c|c|}
\hline Initial evaluation & Subsequent follow-up \\
\hline Screening by ANA in suspected cases of SLE & $\begin{array}{l}\text { Follow-up frequency: } 1-3 \text { months, or even more frequent, for active } \\
\text { SLE; 3-6 months for mild and stable SLE }\end{array}$ \\
\hline $\begin{array}{l}\text { Clinical history and physical examination for skin/scalp lesions, arthritis, } \\
\text { lymphadenopathy, alopecia, mucosal ulceration, and Raynaud's } \\
\text { phenomenon. Enquire for family history of SLE or other autoimmune } \\
\text { diseases }\end{array}$ & $\begin{array}{l}\text { Focused history on new symptoms/manifestations. Differentiate disease } \\
\text { activity from organ damage, drug toxicities, and co-morbidities that are } \\
\text { causing the symptoms }\end{array}$ \\
\hline $\begin{array}{l}\text { Drug review, particularly those that may induce ANA autoimmunity, } \\
\text { eg, isoniazid, methyldopa, hydralazine, minocycline, carbimazole, and } \\
\text { phenytoin }\end{array}$ & Review medications and adverse effects \\
\hline Vital signs, blood pressure, BMI & Vital signs, blood pressure, BMI, urine protein analysis \\
\hline $\begin{array}{l}\text { If ANA positive, check anti-dsDNA, anti-ENA, complements, } \\
\text { anticardiolipin, cell counts, liver and renal function, ESR, CRP, } \\
\text { immunoglobulin level; urine analysis, baseline chest radiograph }\end{array}$ & $\begin{array}{l}\text { Cell counts, renal and liver function tests, anti-dsDNA, complements, } \\
\text { CRP (for selected patients). Regular surveillance for vascular risk } \\
\text { factors, eg, lipid profile and glucose }\end{array}$ \\
\hline
\end{tabular}

\section{General advice about various health issues}

$\begin{array}{ll}\text { Photoprotection } & \begin{array}{l}\text { Avoid prolonged sun exposure; protective clothing; hat and umbrella; topical sunscreen (SPF } \geq 30) \text { every } 1-2 \\ \text { hours }\end{array} \\ \text { Monitoring of BMD } & \text { Baseline DXA scan; lifestyle modification plus calcium and vitamin D (if prednisolone } \geq 2.5 \text { mg/day for } \geq 3 \\ \text { months); anti-osteoporotic medications if risk of major fracture } \geq 10 \% \text { or hip fracture } \geq 1 \% \text { at } 10 \text { years (age } & \geq 40 \text { years); or history of fragility fracture, BMD Z-score }<-3.0 \text { or rapid loss of } \geq 10 \% \text { BMD in } 1 \text { year (age }<40 \\ & \text { years). Choice: oral BSP }>\text { intravenous BSP }>\text { teriparatide, denosumab, or raloxifene (not for premenopausal } \\ & \text { women); repeat DXA every } 2-3 \text { years }\end{array}$

Review and advice on vaccination Seasonal influenza and pneumococcal vaccines; hepatitis B vaccine (if at risk and not received at birth); haemophilus and meningococcal vaccines (post-splenectomy, persistent low complements); HPV vaccine (age > 9 years); avoid live attenuated vaccine but consider herpes zoster vaccine when not receiving intensive immunosuppression; vaccination should be given during period of disease remission and minimal immunosuppression

Counselling on pregnancy and assisted reproduction

Conception may be considered when disease is in remission for $\geq 6$ months; adjustment of medications to avoid teratogenicity; check anti-Ro and aPL antibodies; ovulation stimulation may be done when disease is in remission for $\geq 6$ months; aspirin and heparin prophylaxis if aPL antibodies positive but no history of thrombosis or other contra-indications

Counselling on contraception

Barrier method; progestogens; progestogen-impregnated IUD; low-dose oestrogen containing combined OC pill is not contra-indicated for stable and quiescent disease and in the absence of aPL antibodies or other contra-indications

Abbreviations: $\mathrm{ANA}=$ antinuclear antibody; $\mathrm{aPL}=$ antiphospholipid; $\mathrm{BMD}=$ bone mineral density; $\mathrm{BMI}=$ body mass index; $\mathrm{BSP}=$ bisphosphonate; $\mathrm{CRP}=$ C-reactive protein; DXA = dual-energy X-ray absorptiometry; ENA = extractable nuclear antigen; ESR = erythrocyte sedimentation rate; HPV = human papillomavirus; IUD = intrauterine device; OC = oral contraceptive; SLE = systemic lupus erythematosus; SPF = sun protection factor

treatment, ${ }^{24}$ surveillance for vascular risk factors such as body mass index, blood pressure, fasting lipid profile, and glucose should be done at regular intervals. Erythrocyte sedimentation rate and CRP have little role in the monitoring of SLE activity and should only be performed in patients with active synovitis undergoing specific therapy.

\section{Advice on photoprotection}

The ultraviolet (UV) light spectrum can be divided into UVC (100-290 nm), UVB (290-320 nm), and UVA (320-400 $\mathrm{nm}$ ) wavelengths. The superficial layers of the epidermis mainly absorb UVB irradiation, but longer-wavelength UVA can also penetrate the deeper dermis. Ultraviolet light may trigger a complicated process that includes the activation of keratinocytes to release pro-inflammatory cytokines, chemokines, and interferons, which may exacerbate local and systemic autoimmunity. ${ }^{25}$

Photosensitivity was poorly described in the ACR criteria as skin rash resulting from an unusual reaction to sunlight, as reported in patients' history or physicians' observation. ${ }^{10,11}$ Some clinicians regard photosensitivity as induction or exacerbation of skin lesions after extensive sun exposure, which also includes sunburn. Because of the broad definition of photosensitivity, its incidence in SLE ranges widely (27\%-100\% in different studies). ${ }^{25}$ The latency period between UV exposure and skin eruptions can range from several days to 3 weeks. In addition to UV exposure, photosensitivity in SLE can be caused by photosensitising medications and co-existing photodermatosis.

Avoidance of excessive sunshine, particularly during midday hours, is often advised to patients with SLE. Hats, protective clothing, and umbrellas are effective at blocking UV light. Ultraviolet- 
protective sunglasses and lip balms may also help. Topical sunscreen is a common means of reducing UV light penetration. A sunscreen with sun protection factor 30 absorbs/reflects $97 \%$ of UV light. ${ }^{26}$ Patients with SLE should apply sunscreen (sun protection factor $\geq 30$ ) 30 minutes before going out into the sun to all exposed body parts and reapply it after 1 to 2 hours if exposure is to continue. Patients should be reminded that sunscreen does not provide $100 \%$ protection from UV light or offer skin support for repair of photodamage. Therefore, avoidance of unnecessary sun exposure remains the most important behavioural modification.

\section{Vitamin D supplementation and osteoporosis prevention}

Vitamin D deficiency has recently been postulated to be an environmental trigger for autoimmune diseases, including SLE. ${ }^{27}$ Compared with age- and sex-matched healthy subjects, patients with SLE have significantly lower serum vitamin D levels, which correlate inversely with disease activity. ${ }^{28-30}$ Vitamin D insufficiency in SLE has multiple contributing factors, which include avoidance of UV exposure by using sunscreen, chronic kidney disease, long-term use of medications that hamper absorption or metabolism of vitamin D, and anti-vitamin D antibodies that may enhance plasma clearance of vitamin D. ${ }^{27}$ Although there is conflicting evidence regarding the efficacy of vitamin D supplementation at alleviating clinical SLE activity, such supplementation is recommended for prevention and treatment of glucocorticoidinduced osteoporosis. ${ }^{31}$ According to the updated ACR recommendations, patients receiving $\geq 3$ months of prednisolone $(\geq 2.5 \mathrm{mg} /$ day $)$ should receive elemental calcium (1000-1200 mg/day) and cholecalciferol (600-800 IU/day) along with lifestyle modification (weight bearing exercise, cessation of smoking, balanced diet, and maintaining optimal body weight). ${ }^{31}$ In patients with SLE aged $>40$ years, who have a moderate to high risk of a major osteoporotic $(>10 \%)$ or hip fracture $(>1 \%)$ within 10 years (as assessed by the fracture risk assessment tool), oral bisphosphonates are recommended. When oral bisphosphonates are inappropriate (eg, owing to intolerance or contra-indication), intravenous bisphosphonates (eg, zoledronate) are the next alternatives to be considered. Other treatment options include teriparatide (which is costly and inconvenient to inject daily), denosumab, and raloxifene (which has a lack of efficacy data regarding fractures). There is a general paucity of efficacy data of these agents in younger patients aged $<40$ years. The ACR recommends treatment for moderate-to-high-risk younger patients, defined as having a previous osteoporotic fracture; bone mineral density $\mathrm{Z}$-score of $<-3.0$ at the hip or spine; or rapid loss of $\geq 10 \%$ bone mineral density over 1 year and continuous prednisolone treatment $(\geq 7.5$ $\mathrm{mg} /$ day for $\geq 6$ months). ${ }^{31}$ The choice of drugs is the same as that for older patients, except for raloxifene, which is not indicated in premenopausal women or male patients.

\section{Vaccination}

Patients with SLE are prone to infections because of the underlying immune aberrations and therapies with immunosuppressive regimens. ${ }^{1}$ Vaccination offers the most cost-effective method of reducing infection risk in patients with SLE. Non-live vaccines such as influenza and pneumococcal vaccines are generally well tolerated in SLE, although they are less immunogenic than in age-matched individuals. ${ }^{32}$ Although there is conflicting evidence on whether influenza vaccine exacerbates SLE activity, ${ }^{33}$ seasonal influenza vaccination according to national guidelines is recommended..$^{34,35}$ Influenza and pneumococcal vaccination is particularly recommended for patients with SLE before rituximab therapy. Additional vaccinations against Haemophilus influenzae and Neisseria meningitidis are suggested for patients with functional asplenia, splenectomy, or persistently very low complement levels..$^{34,35}$ Hepatitis B vaccination can be safely administered to patients with SLE who are at risk of infection if it was not given at birth. Female patients with SLE are more prone to persistent genital human papillomavirus (HPV) infection, which predisposes them to cervical cancers. The HPV vaccine is recommended for patients with SLE, preferably prior to the beginning of sexual activity. There is no evidence of increased SLE flares after administration of the quadrivalent or bivalent HPV vaccines. ${ }^{36}$ In Hong Kong, the quadrivalent and nonavalent HPV vaccine is licensed for female and male patients aged $\geq 9$ years. ${ }^{37}$ Non-live vaccines should be given to patients with SLE during periods of disease quiescence and minimal immunosuppression.

Live attenuated vaccines are generally not recommended for individuals who are heavily immunocompromised because of the risk of disseminated infections. Of relevance is the live attenuated herpes zoster vaccine, which has been licensed for patients aged $>50$ years. Patients with SLE are particularly prone to herpes zoster reactivation, with a pooled relative risk of 2.10 compared with the age- and sex-matched general population. ${ }^{38}$ According to the United States Advisory Committee on Immunization Practices, herpes zoster vaccine should not be given to individuals who are receiving heavy immunosuppressive therapies, such as prednisolone ( $>20 \mathrm{mg} /$ day for $\geq 2$ weeks), methotrexate $(\geq 0.4 \mathrm{mg} / \mathrm{kg} /$ week), and azathioprine $(\geq 3.0 \mathrm{mg} / \mathrm{kg} /$ day $) .{ }^{39}$ However, in view of the high incidence of herpes zoster in patients with SLE, herpes zoster vaccine should be considered in those 
who have stable and remitted disease that does not require intense immunosuppression. ${ }^{34,35}$ The herpes zoster vaccine has been administered safely to SLE patients without subsequent development of herpetiform lesions or disease flares. ${ }^{40}$

\section{Pregnancy counselling, assisted reproduction, and contraception}

The fertility of patients with SLE is preserved, unless they develop chronic kidney disease or have been treated with cyclophosphamide. Patients with SLE should not be discouraged regarding pregnancy, provided that their disease has been under good control for at least 6 to 12 months. ${ }^{41}$ The outcomes of pregnancies have improved for patients with SLE in the past few decades as a result of better risk stratification, pre-conception counselling, and close multidisciplinary surveillance. However, the rates of pregnancy loss, preterm birth, preeclampsia, and intrauterine growth retardation remain higher in pregnancies of patients with SLE than in those of patients without. ${ }^{41}$ The main risk factors for poor maternal and fetal outcomes in pregnancies of patients with SLE are active disease at conception (particularly nephritis), the presence of strongly positive antiphospholipid antibodies (or a history of obstetric antiphospholipid syndrome), and a history of lupus nephritis. ${ }^{42}$ Some medications such as cyclophosphamide, mycophenolate mofetil, leflunomide, and angiotensin-converting enzyme inhibitors/angiotensin receptor blockers are teratogenic. High-dose glucocorticoid treatment may lead to intrauterine growth retardation and premature delivery. The risk of congenital heart blockage in anti-Ro-positive mothers with SLE is approximately $1 \%$ to $2 \% .{ }^{42}$ Close liaison with obstetricians and paediatricians for monitoring of the cardiovascular status of the fetus during pregnancy and assessment of neonatal lupus syndrome is needed. In general, SLE patients with $\geq 6$ months of disease remission who are in good general health may consider conception. Referral to specialists for adjustment of medications and prophylactic heparin/aspirin (in case of obstetric antiphospholipid syndrome) is needed.

The use of assisted reproductive technology is increasing. Despite increases in disease flares and thrombosis after hormonal ovulation stimulation, ${ }^{43}$ the current recommendation is to individualise the risk of these procedures in patients with SLE. ${ }^{44}$ Assisted reproductive technology procedures should be discouraged in female SLE patients who have active disease, severe renal insufficiency, serious valvulopathy or coronary heart disease, poorly controlled hypertension, history of major thrombotic events, or antiphospholipid syndrome. ${ }^{44}$ Counselling should also be given about other serious adverse effects of assisted reproductive technology procedures, such as ovarian hyperstimulation. In patients with SLE who are positive for antiphospholipid antibodies and have no history of thrombosis, aspirin and heparin prophylaxis is recommended during these procedures. ${ }^{45}$ Similar to naturally achieved pregnancies, the SLE of candidates for assisted reproductive technology should have been quiescent for $\geq 6$ months. ${ }^{46}$

Patients with SLE should be counselled about contraception methods. Barrier methods are generally safe. Oestrogen-containing oral contraceptive pills were discouraged in the past. However, in a randomised double-blind placebo-controlled trial, a combination of oral contraceptive pills was not shown to increase SLE disease flares or thrombosis after 12 months' administration as compared with placebo in patients with stable SLE and no antiphospholipid antibodies. ${ }^{47}$ Another randomised controlled trial did not reveal a difference in disease flares or adverse events in 12 months among patients with SLE who were assigned to receive combined oral contraceptive pill, intrauterine device, and progestogen-only pills for contraception. ${ }^{48}$ Thus, patients with stable SLE and no antiphospholipid antibodies or other contra-indications may use lowdose oestrogen oral contraceptive pills if they want to adopt a more reliable contraceptive method. When oral contraceptive pills are not appropriate, progestogens and intrauterine devices can be offered to patients with SLE as alternatives. ${ }^{44}$ Progestogenimpregnated intrauterine devices have the advantage of reducing the incidence of dysmenorrhoea and irregular vaginal bleeding. ${ }^{44}$

\section{Conventional and novel therapeutics for systemic lupus erythematosus}

Hydroxychloroquine is an antimalarial drug that exhibits immune-modulatory properties in addition to antithrombotic and lipid- and glucose-lowering properties. ${ }^{49}$ Hydroxychloroquine is mainly indicated for skin, joint, and serosal manifestations of SLE and has a glucocorticoid-sparing effect. The drug is compatible with pregnancy and breastfeeding and is relatively safe to be prescribed and monitored by trained family physicians. Allergy and acute ocular and neuromuscular toxicity are rare adverse drug reactions. Chronic use of hydroxychloroquine may lead to retinopathy, with the main risk factors being older age, pre-existing liver and renal dysfunction, higher daily dose, and longer duration of therapy. ${ }^{50,51}$ Early recognition of this adverse drug reaction is essential to minimise damage to vision. Referral to an ophthalmologist for baseline examination and regular retinopathy surveillance is recommended..$^{50}$

In a recent study, 2361 patients received 
hydroxychloroquine for $>5$ years. In that study, the risk of retinopathy was $<1 \%$ in the first 5 years and $<2 \%$ in 10 years when the daily dose was $<5 \mathrm{mg} /$ $\mathrm{kg}$ of real body weight. ${ }^{51}$ The risk of retinopathy increased sharply to $20 \%$ after 20 years. The daily dose of hydroxychloroquine was the most critical factor for the retinopathy risk, which correlated better with real rather than ideal body weight. The American Academy of Ophthalmology recommends a maximum daily hydroxychloroquine dose of $<5.0$ $\mathrm{mg} / \mathrm{kg}$ of real weight to minimise retinal toxicity. ${ }^{50}$ A baseline ophthalmologic examination within the first year of commencement of drug administration is recommended, and annual screening should start after 5 years of exposure in patients using a lower dosage and without major risk factors. Patients with major risk factors for retinopathy (older age, renal or liver dysfunction, or pre-existing macular or retinal disease) should be screened annually if not more frequently..$^{50}$

Short courses of non-steroidal antiinflammatory drugs (NSAIDs) are indicated for control of SLE symptoms such as arthritis, myalgia, serositis, and fever. The risk of allergic and skin reactions, aseptic meningitis, and renal and liver toxicity is increased in SLE patients, despite their younger age. Ovulation may be affected by NSAIDs, and they should be used cautiously during pregnancy. Patients with SLE who have renal insufficiency, bleeding tendency, and pre-existing coronary heart disease should avoid NSAIDs. Except for their lower risk of gastrointestinal toxicity, selective Cox II inhibitors share similar renal, hepatological, and neurological adverse effects with non-selective Cox inhibitors. ${ }^{52}$ Among the NSAIDs, naproxen appears to be associated with the lowest risk of cardiovascular

TABLE 4. Pharmacological therapies for SLE

\begin{tabular}{|c|c|c|c|}
\hline Medication & Indication & Dosage & Monitoring and precaution \\
\hline $\mathrm{HCQ}$ & $\begin{array}{l}\text { Skin and joint disease, lupus } \\
\text { nephritis, and general use to reduce } \\
\text { organ damage }\end{array}$ & $\begin{array}{l}200-400 \mathrm{mg} / \text { day, keep } \leq 200 \\
\mathrm{mg} / \text { day for maintenance to } \\
\text { reduce retinopathy risk }\end{array}$ & $\begin{array}{l}\text { Baseline ophthalmological examination and } \\
\text { regular surveillance }\end{array}$ \\
\hline NSAIDs & Arthritis, fever, serositis & Depends on preparation & $\begin{array}{l}\text { Avoid in chronic kidney disease, history of arterial } \\
\text { thrombosis, and multiple vascular risk factors }\end{array}$ \\
\hline Glucocorticoids & $\begin{array}{l}\text { Low dose for mild disease and } \\
\text { maintenance; moderate to high dose } \\
\text { for major organ disease, eg, nephritis, } \\
\text { neuropsychiatric disease }\end{array}$ & $\begin{array}{l}\text { Low dose: }<10 \mathrm{mg} / \mathrm{day} \\
\text { Moderate dose: } 10 \mathrm{mg} / \text { day- } \\
0.5 \mathrm{mg} / \mathrm{kg} / \text { day } \\
\text { High dose: } \geq 0.5-1.0 \mathrm{mg} / \mathrm{kg} / \text { day }\end{array}$ & $\begin{array}{l}\text { Excludes infection before administration; } \\
\text { monitoring of blood pressure, lipid and glucose } \\
\text { level; prevention of osteoporosis and infections }\end{array}$ \\
\hline Methotrexate & $\begin{array}{l}\text { Arthritis not responding to } \mathrm{HCQ} \text {, } \\
\text { myositis, skin lupus, serositis }\end{array}$ & $7.5-15 \mathrm{mg} /$ day & $\begin{array}{l}\text { May aggravate photosensitivity; monitoring of } \\
\text { liver/renal function, cell counts, chest radiograph } \\
\text { and lung function; contra-indicated in severe renal } \\
\text { insufficiency }\end{array}$ \\
\hline Azathioprine & $\begin{array}{l}\text { Lupus nephritis, more serious organ } \\
\text { disease, glucocorticoid sparing } \\
\text { effects }\end{array}$ & $1-2 \mathrm{mg} / \mathrm{kg} /$ day & $\begin{array}{l}\text { Close monitoring of leukocyte and neutrophil } \\
\text { counts when first used; regular blood counts and } \\
\text { liver function }\end{array}$ \\
\hline MMF & $\begin{array}{l}\text { Lupus nephritis, refractory skin and } \\
\text { more serious organ disease }\end{array}$ & $1-3 \mathrm{~g} /$ day & $\begin{array}{l}\text { Monitoring for gastrointestinal intolerance and cell } \\
\text { counts }\end{array}$ \\
\hline CSA/TAC & $\begin{array}{l}\text { Lupus nephritis, refractory } \\
\text { haematological and more serious } \\
\text { organ disease }\end{array}$ & $\begin{array}{l}\text { TAC: } 0.06-0.1 \mathrm{mg} / \mathrm{kg} / \mathrm{day} \\
\text { CSA: } 3-5 \mathrm{mg} / \mathrm{kg} / \mathrm{day}\end{array}$ & $\begin{array}{l}\text { Monitoring of blood pressure, electrolytes, renal } \\
\text { function, and symptoms of neurotoxicity }\end{array}$ \\
\hline CYC & $\begin{array}{l}\text { Lupus nephritis, neuropsychiatric, } \\
\text { and other serious major organ } \\
\text { diseases }\end{array}$ & $\begin{array}{l}\text { Oral: } 1-2 \mathrm{mg} / \mathrm{kg} / \text { day } \\
\text { Intravenous pulse: } 0.5-1 \mathrm{~g} / \mathrm{m}^{2} \text { per } \\
\text { pulse }\end{array}$ & $\begin{array}{l}\text { Oral regimen no more than } 3 \text { months; pulse } \\
\text { regimen no more than } 6 \text { pulses, unless } \\
\text { neuropsychiatric or more serious manifestations; } \\
\text { monitoring of leukocyte and neutrophil counts } \\
\text { and cystitis; prophylaxis against PCP in selected } \\
\text { patients }\end{array}$ \\
\hline Belimumab & $\begin{array}{l}\text { Moderate to severe SLE } \\
\text { manifestations not responding to } \\
\text { standard of care }\end{array}$ & $\begin{array}{l}10 \mathrm{mg} / \mathrm{kg} \text { intravenous at baseline, } \\
\text { week } 2 \text {, week 4, and then } \\
\text { 4-weekly }\end{array}$ & $\begin{array}{l}\text { Not indicated for serious nephritis, } \\
\text { neuropsychiatric and other serious organ } \\
\text { manifestations; monitor cell counts and for } \\
\text { infusion reaction }\end{array}$ \\
\hline Rituximab & $\begin{array}{l}\text { Refractory SLE manifestations, } \\
\text { particularly lupus nephritis }\end{array}$ & $\begin{array}{l}\text { Intravenous: } 375 \mathrm{mg} / \mathrm{m}^{2} \text { weekly } \\
\text { for } 4 \text { doses or } 1 \mathrm{~g} 2 \text {-weekly for } \\
2 \text { doses (one course) }\end{array}$ & $\begin{array}{l}\text { Prophylaxis for occult hepatitis B reactivation; } \\
\text { monitoring of immunoglobulin level and cell } \\
\text { counts }\end{array}$ \\
\hline $\begin{array}{l}\text { Other biological/ } \\
\text { targeted agents }\end{array}$ & Under clinical trials & $\begin{array}{l}\text { Including atacicept, ustekinumab, } \\
\text { baricitinib, anifrolumab }\end{array}$ & - \\
\hline
\end{tabular}

Abbreviations: $\mathrm{CSA}=$ cyclosporine $\mathrm{A} ; \mathrm{CYC}=$ cyclophosphamide; $\mathrm{HCQ}=$ hydroxychloroquine; $\mathrm{MMF}=$ mycophenolate mofetil; NSAIDs = non-steroidal antiinflammatory drugs; $\mathrm{PCP}=$ pneumocystis pneumonia; $\mathrm{SLE}=$ systemic lupus erythematosus; $\mathrm{TAC}$ = tacrolimus 
events and is the preferred NSAID for patients with multiple cardiovascular risk factors. ${ }^{53}$ Diclofenac is associated with the highest risk and should be avoided in these patients. A recent randomised controlled trial reported that celecoxib was noninferior to ibuprofen or naproxen with regard to cardiovascular safety in patients with rheumatoid arthritis and osteoarthritis. ${ }^{54}$ The lowest effective dose of NSAIDs should be used, and their indications should be periodically reviewed. Monitoring of fluid status, kidney function, liver transaminases, and blood pressure is necessary.

Glucocorticoids and a number of nonglucocorticoid immunosuppressive agents are often used to treat more serious organ manifestations of SLE. Systemic glucocorticoids are a major cause of treatment-related organ damage in patients with SLE and contribute significantly to mortality and co-morbidities. ${ }^{7,55}$ Therefore, the use of systemic glucocorticoids in SLE has to be fully justified, judicious, and closely monitored. Other treatment modalities used for severe SLE include intravenous immunoglobulin and plasmapheresis. A biological agent called belimumab has recently been approved for mild to moderate SLE manifestations that are refractory to standard therapies. ${ }^{56}$ Although rituximab has not been proven to be more effective than placebo in randomised controlled trials, it is often used off-label for refractory lupus manifestations. ${ }^{1}$ Many other biological and targeted synthetic agents are being tested in patients with SLE. While it is outside the scope of this review to describe these therapies in detail, they are summarised in Table 4 for quick reference.

\section{Conclusions}

Systemic lupus erythematosus is a prototypical autoimmune disease that affects primarily young women of reproductive age. The new SLICC classification has expanded the clinical and serological criteria for its classification. Systemic lupus erythematosus should never be diagnosed based solely on positive test results for antibodies, particularly ANA, which is highly non-specific and should be interpreted in conjunction with clinical signs and symptoms. In view of the disease's multisystemic involvement, holistic care is necessary to formulate treatment plans for individual patients. Family physicians play an important role in establishing an early diagnosis, treatment and monitoring of mild disease, and making referrals to specialists when appropriate. Education, counselling, and psychological support are equally important to improve treatment adherence and alleviate mood symptoms. General advice about photoprotection, vaccination, prevention of osteoporosis, and reproductive issues may be given in the primary care setting. Hydroxychloroquine is a relatively safe drug that can be commenced and monitored by family physicians. For patients with stable SLE, screening for cardiovascular risk factors and osteoporosis may also be performed periodically in family clinics.

\section{Author contributions}

The author has made substantial contributions to the concept or design, acquisition of data, analysis or interpretation of data, drafting of the article, and critical revision for important intellectual content.

\section{Declaration}

The author has disclosed no conflicts of interest. The author had full access to the data, contributed to the study, approved the final version for publication, and take responsibility for its accuracy and integrity.

\section{References}

1. Mok CC. Biological and targeted therapies of systemic lupus erythematosus: evidence and the state of the art. Expert Rev Clin Immunol 2017;13:677-92.

2. Mok CC. Epidemiology and survival of systemic lupus erythematosus in Hong Kong Chinese. Lupus 2011;20:76771.

3. Mok CC, Kwok CL, Ho LY, Chan PT, Yip SF. Life expectancy, standardized mortality ratios, and causes of death in six rheumatic diseases in Hong Kong, China. Arthritis Rheum 2011;63:1182-9.

4. Mok CC, Kosinski M, Ho LY, Chan KL, Jolly M. Validation of the LupusPRO in Chinese patients from Hong Kong with systemic lupus erythematosus. Arthritis Care Res (Hoboken) 2015;67:297-304.

5. Mok CC, Ho LY, Cheung MY, Yu KL, To CH. Effect of disease activity and damage on quality of life in patients with systemic lupus erythematosus: a 2-year prospective study. Scand J Rheumatol 2009;38:121-7.

6. Mok CC. Emerging biological therapies for systemic lupus erythematosus. Expert Opin Emerg Drugs 2014;19:303-22.

7. Mok CC, Tse SM, Chan KL, Ho LY. Effect of immunosuppressive therapies on survival of systemic lupus erythematosus: a propensity score analysis of a longitudinal cohort. Lupus 2018;27:722-7.

8. Mok CC, Cheung MY, Ho LY, Yu KL, To CH. Risk and predictors of work disability in Chinese patients with systemic lupus erythematosus. Lupus 2008;17:1103-7.

9. Lam NC, Ghetu MV, Bieniek ML. Systemic lupus erythematosus: primary care approach to diagnosis and management. Am Fam Physician 2016;94:284-94.

10. Tan EM, Cohen AS, Fries JF, et al. The 1982 revised criteria for the classification of systemic lupus erythematosus. Arthritis Rheum 1982;25:1271-7.

11. Hochberg MC. Updating the American College of Rheumatology revised criteria for the classification of systemic lupus erythematosus. Arthritis Rheum 1997;40:1725.

12. Petri M, Orbai AM, Alarcón GS, et al. Derivation and validation of the Systemic Lupus International Collaborating Clinics classification criteria for systemic lupus erythematosus. Arthritis Rheum 2012;64:2677-86.

13. Pisetsky DS. Antinuclear antibody testing-misunderstood or misbegotten? Nat Rev Rheumatol 2017;13:495-502.

14. Rigon A, Infantino $M$, Merone $M$, et al. The inter- 
observer reading variability in anti-nuclear antibodies indirect (ANA) immunofluorescence test: A multicenter evaluation and a review of the literature. Autoimmun Rev 2017;16:1224-9.

15. Emlen W, O'Neill L. Clinical significance of antinuclear antibodies: comparison of detection with immunofluorescence and enzyme-linked immunosorbent assays. Arthritis Rheum 1997;40:1612-8.

16. Dellavance A, Viana VS, Leon EP, Bonfa ES, Andrade LE, Leser PG. The clinical spectrum of antinuclear antibodies associated with the nuclear dense fine speckled immunofluorescence pattern. J Rheumatol 2005;32:2144-9.

17. Infantino M, Meacci F, Grossi V, et al. The clinical impact of anti-DFS70 antibodies in undifferentiated connective tissue disease: case reports and a review of the literature. Immunol Res 2017;65:293-5.

18. Mahler M, Hanly JG, Fritzler MJ. Importance of the dense fine speckled pattern on HEp-2 cells and anti-DFS70 antibodies for the diagnosis of systemic autoimmune diseases. Autoimmun Rev 2012;11:642-5.

19. Mariz HA, Sato EI, Barbosa SH, Rodrigues SH, Dellavance A, Andrade LE. Pattern on the antinuclear antibody-HEp-2 test is a critical parameter for discriminating antinuclear antibody-positive healthy individuals and patients with autoimmune rheumatic diseases. Arthritis Rheum 2011;63:191-200.

20. Seelig CA, Bauer O, Seelig HP. Autoantibodies against DFS70/LEDGF exclusion markers for systemic autoimmune rheumatic diseases (SARD). Clin Lab 2016;62:499-517.

21. Mok CC. Systemic lupus erythematosus: when to refer? HK Pract 2002;24:444-9.

22. Mok CC, To CH, Mak A. Neuropsychiatric damage in Southern Chinese patients with systemic lupus erythematosus. Medicine (Baltimore) 2006;85:221-8.

23. Mok CC, Ho LY, Tse SM, Chan KL. Prevalence of remission and its effect on damage and quality of life in Chinese patients with systemic lupus erythematosus. Ann Rheum Dis 2017;76:1420-5.

24. Mok CC. Accelerated atherosclerosis, arterial thromboembolism, and preventive strategies in systemic lupus erythematosus. Scand J Rheumatol 2006;35:85-95.

25. Kuhn A, Wenzel J, Bijl M. Lupus erythematosus revisited. Semin Immunopathol 2016;38:97-112.

26. Obermoser G, Zelger B. Triple need for photoprotection in lupus erythematosus. Lupus 2008;17:525-7.

27. Mok CC. Vitamin D and systemic lupus erythematosus: an update. Expert Rev Clin Immunol 2013;9:453-63.

28. Shahin D, El-Farahaty RM, Houssen ME, et al. Serum 25-OH vitamin D level in treatment-naïve systemic lupus erythematosus patients: relation to disease activity, IL-23 and IL-17. Lupus 2017;26:917-26.

29. Mok CC, Birmingham DJ, Leung HW, Hebert LA, Song H, Rovin BH. Vitamin D levels in Chinese patients with systemic lupus erythematosus: relationship with disease activity, vascular risk factors and atherosclerosis. Rheumatology (Oxford) 2012;51:644-52.

30. Amital H, Szekanecz Z, Szücs G, et al. Serum concentrations of $25-\mathrm{OH}$ vitamin $\mathrm{D}$ in patients with systemic lupus erythematosus (SLE) are inversely related to disease activity: is it time to routinely supplement patients with SLE with vitamin D? Ann Rheum Dis 2010;69:1155-7.

31. Buckley L, Guyatt G, Fink HA, et al. 2017 American College of Rheumatology Guideline for the prevention and treatment of glucocorticoid-induced osteoporosis. Arthritis Rheumatol 2017;69:1521-37.

32. Pugès $M$, Biscay $P$, Barnetche $T$, et al. Immunogenicity and impact on disease activity of influenza and pneumococcal vaccines in systemic lupus erythematosus: a systematic literature review and meta-analysis. Rheumatology (Oxford) 2016;55:1664-72.

33. Murdaca G, Orsi A, Spanò F, et al. Vaccine-preventable infections in systemic lupus erythematosus. Hum Vaccin Immunother 2016;12:632-43.

34. van Assen S, Agmon-Levin N, Elkayam O, et al. EULAR recommendations for vaccination in adult patients with autoimmune inflammatory rheumatic diseases. Ann Rheum Dis 2011;70:414-22.

35. Heijstek MW, Ott de Bruin LM, Bijl M, et al. EULAR recommendations for vaccination in paediatric patients with rheumatic diseases. Ann Rheum Dis 2011;70:1704-12.

36. Mok CC, Ho LY, Fong LS, To CH. Immunogenicity and safety of a quadrivalent human papillomavirus vaccine in patients with systemic lupus erythematosus: a case-control study. Ann Rheum Dis 2013;72:659-64.

37. Cervical screening programme, Department of Health, Hong Kong SAR Government. Available from: https:// www.cervicalscreening.gov.hk/english/hum/hum_ccv. html\#4. Accessed 1 May 2018.

38. Kawai K, Yawn BP. Risk factors for herpes zoster: a systematic review and meta-analysis. Mayo Clin Proc 2017;92:1806-21.

39. Harpaz R, Ortega-Sanchez IR, Seward JF; Advisory Committee on Immunization Practices (ACIP), Centers for Disease Control and Prevention. Prevention of herpes zoster: recommendations of the Advisory Committee on Immunization Practices (ACIP). MMWR Recomm Rep 2008;57:1-30.

40. Guthridge JM, Cogman A, Merrill JT, et al. Herpes zoster vaccination in SLE: a pilot study of immunogenicity. J Rheumatol 2013;40:1875-80.

41. Fischer-Betz R, Specker C. Pregnancy in systemic lupus erythematosus and antiphospholipid syndrome. Best Pract Res Clin Rheumatol 2017;31:397-414.

42. Peart E, Clowse ME. Systemic lupus erythematosus and pregnancy outcomes: an update and review of the literature. Curr Opin Rheumatol 2014;26:118-23.

43. Orquevaux P, Masseau A, Le Guern V, et al. In vitro fertilization in 37 women with systemic lupus erythematosus or antiphospholipid syndrome: a series of 97 procedures. J Rheumatol 2017;44:613-8.

44. Andreoli L, Crisafulli F, Tincani A. Pregnancy and reproductive aspects of systemic lupus erythematosus. Curr Opin Rheumatol 2017;29:473-9.

45. Andreoli L, Bertsias GK, Agmon-Levin N, et al. EULAR recommendations for women's health and the management of family planning, assisted reproduction, pregnancy and menopause in patients with systemic lupus erythematosus and/or antiphospholipid syndrome. Ann Rheum Dis 2017;76:476-85.

46. Levine AB, Lockshin MD. Assisted reproductive technology in SLE and APS. Lupus 2014;23:1239-41.

47. Petri M, Kim MY, Kalunian KC, et al. Combined oral contraceptives in women with systemic lupus erythematosus. N Engl J Med 2005;353:2550-8.

48. Sánchez-Guerrero J, Uribe AG, Jiménez-Santana L, et al. A trial of contraceptive methods in women with systemic 
lupus erythematosus. N Engl J Med 2005;353:2539-49.

49. Ponticelli C, Moroni G. Hydroxychloroquine in systemic lupus erythematosus (SLE). Expert Opin Drug Saf 2017;16:411-9.

50. Marmor MF, Kellner U, Lai TY, Melles RB, Mieler WF; American Academy of Ophthalmology. Recommendations on screening for chloroquine and hydroxychloroquine retinopathy (2016 revision). Ophthalmology 2016;123:1386-94.

51. Melles RB, Marmor MF. The risk of toxic retinopathy in patients on long-term hydroxychloroquine therapy. JAMA Ophthalmol 2014;132:1453-60.

52. Ostensen M, Villiger PM. Nonsteroidal anti-inflammatory drugs in systemic lupus erythematosus. Lupus 2000;9:56672 .
53. Pelletier JP, Martel-Pelletier J, Rannou F, Cooper C. Efficacy and safety of oral NSAIDs and analgesics in the management of osteoarthritis: evidence from reallife setting trials and surveys. Semin Arthritis Rheum 2016;45(4 Suppl):S22-7.

54. Nissen SE, Yeomans ND, Solomon DH, et al. Cardiovascular safety of celecoxib, naproxen, or ibuprofen for arthritis. N Engl J Med 2016;375:2519-29.

55. Tarr T, Papp G, Nagy N, Cserép E, Zeher M. Chronic highdose glucocorticoid therapy triggers the development of chronic organ damage and worsens disease outcome in systemic lupus erythematosus. Clin Rheumatol 2017;36:327-33.

56. Hahn BH. Belimumab for systemic lupus erythematosus. $\mathrm{N}$ Engl J Med 2013;368:1528-35. 